\title{
Regulatiivinen pilari hallinnon institutionaalisessa muutoksessa: Tapaustutkimus Suomen ortodoksisen kirkon työsuhdekäytännöistä
}

\author{
Tuomo Peltonen
}

\begin{abstract}
The purpose of this article is to advance empirically grounded understanding about the institutional change of Finnish public administration. The review focuses on the employment practices, employing Scott's institutional theory of the three institutional pillars, and highlighting the role of the regulative element. The subject of the case study is the Finnish Orthodox Church, which operates as a public entity, and which in 2006 transferred from the civil servant system to an employment contract-based system. Longitudinal case analysis demonstrates how the meaning of employment practices gradually shifts from new public management emphases, first towards emphasis on professional norms, and finally towards a preoccupation with the principles of regulatory and legal appropriateness. The case study shows how the legal and regulatory aspects of employment can become a leading issue in determining the legitimacy of a public sector organization. Implications for further study on institutional change and employment practices are discussed.
\end{abstract}

Keywords: public administration, institutional change, employment, regulation, orthodox church

\section{JOHDANTO}

Tämä artikkeli tarkastelee julkishallinnon institutionaalista muutosta ja erityisesti työsuhdekäytäntöjen muuttumista julkisyhteisöjen kontekstissa. Empiirisenä tutkimuskohteena on Suomen ortodoksinen kirkko ja sen työsuhdekäytäntöjen muutos vuosina 2002-2020.
Aiempi tutkimus on tarkastellut laajasti uuden julkisjohtamisen paradigman seurauksia julkisyhteisöissä (esim. Siltala 2013). Julkisjohtamisen uuden mallin on nähty toteutuvan erityisesti henkilöstöjohtamiseen liittyvien reformien kautta (Brown 2004; Bach 2019). Kiinnostuksen kohteena ovat olleet muun muassa työhyvinvointipyrkimysten, yliopistojen henkilöstön vakinaistamispolkujen ja uuden palkkausjärjestelmän kaltaisten henkilöstökäytäntöjen rooli julkishallinnon uudistamisessa (Lehto \& Viitala 2016; Kallio ym. 2016; Siekkinen 2019). Vähemmälle huomiolle ovat jääneet henkilöstön työsuhteeseen ottamiseen, työsuhteessa pitämiseen ja irtisanomiseen liittyvät varsinaiset työsuhdekäytännöt, jotka osaltaan välittävät institutionaalisen muutoksen toteutumista julkisorganisaatioissa (Bach \& Bordogna 2011; Colley, McCourt \& Waterhouse 2012).

Tutkimuskeskustelussa on tuotu esiin uuden julkisjohtamisen asettuminen olemassa olevien institutionaalisten organisointilogiikoiden yhteyteen (Barzelay \& Gallego 2006). Institutionaalisen muutoksen jännitteisyyttä ja kerrostuneisuutta on tarkasteltu ennen muuta uuden julkisjohtamisen ja professionaalisen kulttuurin välisenä vuorovaikutuksena (Kallio ym. 2016; Canhilal, Lepori \& Seeber 2016). Muista institutionaalisen teorian käsitteellisistä viitekehyksistä poiketen Scott:in (2008a) esittelemässä lähestymistavassa on uuden julkisjohtamisen ja professionaalisen järjestelmän rinnalla keskusteltu regulatiivisen instituution ja siihen liittyvien organisointilogiikoiden roolista institutionaalisen muutoksen prosesseissa. Regulatiivisen pilariin liittyvät muodollisten sääntöjen ja pakottavien rangaistusten piirteet saattavat näytellä merkit- 
tävää roolia julkishallinnon uudistusten realisoitumisessa (Caronna 2004).

Tämän artikkelin tarkoituksena on lisätä empiiristä tietämystä suomalaisen hallinnon institutionaalisesta muutoksesta uuden julkisjohtamisen vaikutuksessa (Herranen 2015). Tarkastelu kohdistuu organisaatioiden työsuhdekäytäntöihin, joita ei ole aiemmin systemaattisesti tutkittu moninaisten institutionaalisen logiikkojen kohtaamispaikkana. Institutionaalista muutosta lähestytään Scott:in (2008a) kolmen pilarin välisen vuorovaikutuksen viitekehyksestä käsin, huomioon ottaen aiemmassa tutkimuksessa sivuutettu regulatiivinen elementti (Hoffman 1999). Tapaustutkimuksen kohteena on Suomen ortodoksinen kirkko, joka on toinen valtionkirkkomme, ja jossa on vuonna 2006 toteutettu uuden julkisjohtamisen mukainen siirtyminen henkilöstön virkasuhteista työsopimussuhteiseen palvelumuotoon.

Artikkeli rakentuu siten, että seuraavassa kahdessa osiossa esitellään Scott:in kolmen institutionaalisen pilarin viitekehys sen dynaamisessa muodossa ja keskustellaan työsuhdekäytännöistä institutionaalisen muutoksen kohteina ja välittäjinä erityisesti regulatiivisen pilarin kontekstissa. Tämän jälkeen esitellään empiirisen tutkimuksen aineisto ja kulku. Viidennessä kappaleessa esitellään institutionaalisen muutoksen etenemisen vaiheet tapausorganisaatiossa. Viimeinen osio tiivistää analyysin tärkeimmät tulokset ja esittää joitain suosituksia hallinnon institutionaalisen muutoksen ja työsuhdekäytäntöjen jatkotutkimukselle.

\section{JULKISHALLINNON INSTITUTIONAALINEN MUUTOS JA REGULATIIVINEN PILARI}

Institutionaalinen teoria tarkastelee organisaatioita laajempien yhteiskunnallisten rakenteiden ja merkitysten aktualisoitumisen paikkoina (DiMaggio \& Powell, 1983; Powell \& DiMaggio 2012). Scott:in (2008a) mukaan organisaatioiden instituoituminen tapahtuu kolmen eri elementin tai pilarin ("pillar") yhteisvaikutuksessa. Näistä regulatiivinen pilari käsittää valtiollisen säätelyjärjestelmän asettamat lait, säädökset ja ohjeet, joiden vaikutus organisaation toimintaan perustuu muodollisten sääntöjen pakottavaan luonteeseen. Regulatiivisessa ulottuvuudessa julkinen valta ja sille rinnasteiset instituu- tiot säätävät virallisia normeja, joiden noudattamista valvotaan oikeudellisten rangaistusten uhalla. Normatiivinen pilari puolestaan koostuu epämuodollisista arvoista ja uskomuksista, jotka muodostavat yhtenäisiä kulttuurisia normeja ja niihin liittyviä epävirallisia sääntöjä. Normatiiviset instituutiot rakentuvat arvosidonnaista oletuksista, jotka ohjaavat yhteisön toimintaa ja toimijoiden välisiä suhteita. Kulttuuris-kognitiivinen pilari puolestaan käsittää sosiaalista todellisuutta rakentavat käsitykset, merkitykset ja mentaaliset mallit. Organisaatiota hahmottavat symbolit, käsitteelliset konstruktiot ja kognitiiviset kehykset luonnehtivat tätä institutionaalisen ympäristön ulottuvuutta.

Scott ym. (2000) painottavat sitä, että organisaation toimintaa määrittävät erityyppiset institutionaaliset organisointilogiikat vaikuttavat niille ominaisen pilarin kautta. Perinteinen byrokraattinen organisointilogiikka muokkaa toimintaa ennen muuta regulatiivisen pilarin kautta (Caronna 2004). Byrokraattisen logiikan korostamat objektiivisuuden, tasapuolisuuden ja sääntösidonnaisuuden periaatteet (Weber 1947) toteutuvat selvimmin suhteessa muodolliseen, oikeudelliseen säätelyyn. Professionaalinen logiikka sen sijaan nojaa vahvasti normatiiviseen pilariin (Scott 2008b). Profession luonteeseen kuuluu yhteisön jäseniä sitovat arvot, normit ja ihanteet, jotka luovat perustan yhdenmukaisille tavoille arvioida tilanteita ja ratkaista ongelmia. Uuden julkisjohtamisen logiikka taas vaikuttaa toiminnan ja ajattelun rakentumiseen pääasiallisesti kulttuuris-kognitiivisen pilarin kautta. Uusi julkisjohtaminen tarjoaa vaihtoehtoisia käsitteellisiä konstruktioita ja ajatuksellisia paradigmoja, joiden kautta organisaatiot ja organisointi voidaan ymmärtää uudella tavalla (Christensen \& Lægreid 2011) (Taulukko 1).

Scott:in (2008a) kolmen pilarin muodostama institutionaalisten prosessien viitekehys tarjoaa näkökulman institutionaalisen muutoksen kuvaamiseen organisaatiologiikkojen välisissä muuttuvissa suhteissa. Hirsch:in (1997) mukaan Scott:in kolmen pilarin viitekehystä tulisi ymmärtää eri institutionaalisten sfäärien välisenä vuorovaikutteisena kehityskulkuna tai prosessina. Dynamiikka realisoituu pääosin murroksissa, joissa institutionaalinen järjestys tai konstellaatio vaihtuu toiseen (Hoffman 1999; Li ym. 2008). 
Taulukko 1. Institutionaaliset pilarit. Soveltaen: $\operatorname{Scott}(2008,52)$.

\begin{tabular}{|l|l|l|l|}
\hline & Regulatiivinen pilari & $\begin{array}{l}\text { Normatiivinen } \\
\text { pilari }\end{array}$ & $\begin{array}{l}\text { Kulttuuris- } \\
\text { kognitiivinen pilari }\end{array}$ \\
\hline Järjestyksen perusta & Regulatiiviset säännöt & Sitovat odotukset & $\begin{array}{l}\text { Todellisuutta rakentavat } \\
\text { käsitykset ja mallit }\end{array}$ \\
\hline Ilmenemismuodot & $\begin{array}{l}\text { Lait, säännöt, } \\
\text { rangaistukset }\end{array}$ & $\begin{array}{l}\text { Sertifiointi } \\
\text { Akkreditointi }\end{array}$ & $\begin{array}{l}\text { Yhteiset uskomukset } \\
\text { Jaetut tulkintakehykset }\end{array}$ \\
\hline Hallitseva tunne & Syyttömyys, viattomuus & Kunnia & Varmuus \\
\hline $\begin{array}{l}\text { Vastaava } \\
\text { organisointilogiikka }\end{array}$ & Byrokraattinen & Professionaalinen & Uusi julkisjohtaminen \\
\hline
\end{tabular}

Institutionaalisessa muutoksen kulussa ratkaisevaksi muodostuu se, miten vallitsevaa hegemoniaa haastava institutionaalinen järjestelmä kykenee muovaamaan muiden pilarien sisältöjä tai roolia (Caronna 2004). Muutosprosesseissa uuden institutionaalisen logiikan kattava ulottuminen edellyttää, että toissijaiset pilarit saadaan käännettyä tukemaan nousevan institutionaalisen järjestelmän oletuksia, normeja ja sääntöjä. Uuden julkisjohtamisen levittäytyessä julkisten organisaatioiden kentille julkisjohtamisen paradigman on vakiintuakseen kyettävä vaikuttamaan toissijaisten regulatiivisen ja normatiivisen pilarien sisältöön ja roolin (Barzelay \& Gallego 2006). Institutionaalisen muutoksen näkökulmasta esille nousee erityisesti regulatiivisen pilarin rooli uuden julkisjohtamisen vakiintumisessa, sillä regulatiivinen elementti on muodollisia sääntöjä ja sääntöjen pakottavaa noudattamista korostavana ulottuvuutena vastakkainen kulttuuris-kognitiiviselle pilarille (Scott 2008a; Caronna 2004).

Regulatiivisen pilarin merkitys institutionaalisissa prosesseissa on herättänyt viime aikoina uutta kiinnostusta tutkijoiden parissa (Peton \& Pezé 2014; Trevino ym. 2008). Valtiollisen sääntelyn rooli organisatorisissa käytännöissä auttaa ymmärtämään paremmin institutionaalisen muutoksen kulkua tapauksissa, joissa regulatiivinen pilari on heikentyessään tarjonnut tilaa normatiiviselle ja kulttuuris-kognitiiviselle pilarille, mutta myös muutoksissa, joissa regulatiivisen pilarin jatkunut tai uudelleen vahvistunut vaikutus on mutkistanut uuden julkisjohtamisen logiikan vakiintumista julkishallinnossa (Caronna 2004; Beszter, Ackers \& Hislop 2015).
Regulatiivinen elementti on näin ymmärrettynä aktiivinen elementti institutionaalisen muutoksen kehkeytymisessä, ja sen potentiaalinen rooli tulisi ottaa huomioon pyrittäessä kuvaamaan ja ymmärtämään hallinnon transformaatiota konkreettisissa kehityskuluissa (Edelman, Uggen \& Erlanger 1999).

\section{TYÖSUHDEKÄYTÄNNÖT INSTITUTIONAALISEN MUUTOKSEN KOHTEINA JA VÄLITTÄJINÄ}

Organisaatioiden työsuhteiden hallintaan liittyvät toimet ja linjaukset ovat eräs merkittävä muutoksia välittävä käytäntö institutionaalisissa prosesseissa ja muutoksissa. Julkishallinnon työsuhdekäytännöt ovat perinteisesti noudattaneet byrokraattista logiikkaa, jota on ilmentänyt työntekijöiden sitoutuminen virkamiesetiikan mukaisiin tasapuolisuuden ja neutraaliuden arvoihin, samoin kuin työsuhteiden painottuminen vakaisiin urapolkuihin organisaatioiden sisäisillä työmarkkinoilla (Bach \& Kessler 2007). Organisatorisesti julkisyhteisöjen työntekijöiden työnkuvat ovat olleet selvästi määriteltyjä ja verraten kapeita.

Vakiintunut järjestys on kuitenkin murtunut viime vuosikymmeninä uuden julkisjohtamisen paradigman leviämisen ja vakiintumisen myötä (Brown 2004). Uusi julkisjohtaminen korostaa henkilöstöä strategisena resurssina, jolla pyritään varmistamaan kilpailukykyinen ja markkinamuutoksiin sopeutuva kokonaisuus (Bach 2019). Uusi paradigma on vaikuttanut työsuhdekäytäntöihin siten, että työurat ovat muuttuneet katkonaisimmiksi työsuhteiden määräaikai- 
suuksien ja yksiköiden rakenneratkaisujen myötä. Henkilöstön työnkuvat ovat myös vaihtuneet aiempaa laajemmiksi ja väljemmiksi julkisorganisaatioiden korostaessa henkilöstön valmiutta osallistua moniammatillisiin tiimeihin ja innovaatioprosesseihin. Uuden julkisjohtamisen logiikan näkemyksissä henkilöstövalintojen tulisi perustua ennen muuta toimivan johdon ja esimiesten näkemyksiin ehdokkaiden sopivuudesta suhteessa strategisiin tavoitteisiin (Colley, McCourt \& Waterhouse 2012).

Suomessa virkasuhteiden oikeudellinen asema on lähestynyt työsopimussuhdetta (Kulla 2006), minkä lisäksi joillain julkisilla aloilla on siirrytty osittain tai kokonaan työsuhteisiin palvelusmuotona (Mäkinen 2009). Siirtymä työsuhteisiin liittyy uuden julkisjohtamisen paradigmaan siten, että työsopimussuhteen ajatellaan palvelevan paremmin tavoiteltua joustavampaa toimintamuotoa, jossa julkisyhteisöjen henkilöstön koostumusta ja työehtoja voidaan vapaammin järjestellä strategisten tavoitteiden saavuttamiseksi (esim. HE 7/2009 vp.; 34;63).

Työsuhdekäytäntöjen institutionaalisessa muutoksessa piilee kuitenkin regulatiivisesta näkökulmasta tarkasteltuna potentiaalinen jännite. Julkisoikeudellisesta virkamiesympäristöstä irtaantuminen ei ole poistanut valtiollisen sääntelyn läsnäoloa työsuhdemuotoon siirtyneissä julkisyhteisöissä. Yksityisoikeudellista työsopimussuhdetta säätelevät Suomessa valtiolliset työsopimus- ja yhdenvertaisuuslait, minkä lisäksi työsuhteiden pääpiirteet sovitaan lain määrittämällä tavalla työnantajien ja työtekijöiden välisissä työehtosopimusneuvotteluissa (Työ-ja elinkeinoministeriö 2015). Regulatiivinen pilari voi nousta merkittävään roolin esimeriksi, mikäli työsuhteeseen liittyvät ongelmat tai erimielisyydet johtavat vallitsevien käytäntöjen oikeudelliseen arviointiin ja tätä kautta laajempaan julkiseen tietoisuuteen (vrt. Hoffman 1999). Työelämän sääntely voi myös muuttua tavalla, joka tuottaa uusia oikeuksia työntekijöille (Paanetoja 2015). Työsopimuksia ja työehtoja säätelevä normisto on monitahoista, ja sen juridisesti vakuuttava hallinta edellyttää organisaatiolta pitkälle vietyä laillista ja työelämäjärjestelmän hallintaa (Dobbin ym. 1993). Regulatiivisen pilarin aktivoitumisen myötä uuden julkisjohtamisen johdattama institutionaalinen muutos voi häiriintyä regulatiiviselle elementille tyypillisten byrokraat- tisen logiikan teemojen, kuten oikeudenmukaisuuden ja tasapuolisuuden noustessa työsuhdekysymyksiä kehystäviksi kysymyksiksi (Caronna 2004).

\section{EMPIIRINEN ANALYYSI SUOMEN ORTODOKSISEN KIRKON INSTITUTIONAALISESTA MUUTOKSESTA}

Tämän artikkelin empiirinen analyysi muodostuu Suomen ortodoksisen kirkon (SOK) institutionaalista muutosta ja työsuhdekäytäntöjä käsittelevästä tapaustutkimuksesta. SOK koostuu keskushallinnosta, kolmesta hiippakunnasta ja 21:sta seurakunnasta (Suomen ortodoksinen kirkko, 2020). Kirkon parissa työskentelee 200 työntekijää, joista noin puolet on papillisissa tehtävissä (Tarukannel 2020). SOK on toinen niin sanottu valtionkirkko, mikä tarkoittaa, että sen asema on säädetty lailla, ja että sillä on verotusoikeus. Evankelis-luterilaisesta kirkosta poiketen ortodoksikirkko ei ole uskonnollisesti täysin itsenäinen, vaan se kuuluu Konstantinopolin ekumeenisen patriarkaatin alaisuuteen autonomisena paikalliskirkkona (Ketola 2008, 45-54).

Artikkelin tapaustutkimus perustuu laadulliseen analyysiin (Koskinen, Peltonen \& Alasuutari 2005). Suomen ortodoksisen kirkon institutionaalista muutosta ja työsuhdekäytäntöjen organisoitumista on tarkasteltu dokumentti- ja tekstiaineiston avulla. Materiaali koostuu lähinnä kirkon omista julkaisuista, joita ovat päätöksentekoelinten linjaukset, mietinnöt ja tiedotteet sekä hallintoa käsittelevät toimintasuunnitelmat. Lisäksi aineistona on käytetty oikeudellisia materiaaleja, jotka sisältävät lainvalmisteluun, säädettyihin lakeihin ja oikeuskäytäntöön liittyviä dokumentteja. Kolmantena aineistolähteenä on käytetty SOK:n hallintokäytäntöjä ja työsuhdekysymyksiä käsitelleitä artikkeleita kirkollisissa ja yleismedioissa. Aineistoa kertyi yhteensä noin 200 sivua ja se sijoittuu ajallisesti vuoden 2006 lainmuutosta edeltäneestä keskustelusta aina vuoden 2020 tapahtumiin.

Aineiston tulkinnassa institutionaaliset pilarit on ymmärretty siten, että regulatiivisen pilarin vaikutusta ilmentävät huomion kohteeksi joutuneet oikeudellisten ratkaisujen ja tarkastelujen päätökset ja niiden vaikutukset organisaation tietoisuudessa (Edelman, Uggen \& Erlanger 1999), kun taas normatiivisen pilarin 
logiikkaa edustavat eritoten pappeuden profession (Gannon 1971) mukaiset normit ja toimintatavat työsuhdekäytännöissä. Pappeuden professio ymmärretään tässä tapaustutkimuksessa ortodoksisen kirkon maailmanlaajuisten kanonisten sääntöjen ja eettisten velvoitteiden muodostamaksi normatiiviseksi järjestelmäksi (Parrukoski 1989). Kulttuuris-kognitiivista pilaria puolestaan ilmentävät työsuhteen uutta todellisuutta rakentavat mentaaliset mallit ja kulttuuriset merkitykset, jotka korostavat työsuhteeseen ottamisen ja työvoiman käytön tilannekohtaista joustavuutta sekä organisatorisen strategian toteuttamista työsuhdekäytäntöjen määrittymisessä (Brown 2004). Kulttuuris-kognitiivisen elementin työsuhteisiin kohdistuva logiikka ammentaa pääosin uuden julkisjohtamisen diskursseista (Christensen \& Lægreid 2011; Bach \& Kassler 2007).

Empiirisen aineiston kuvaus seurasi institutionaalisen muutoksen prosessuaalista tarkastelutapaa (Suddaby \& Greenwood 2008). Metodologisesti muutoksen jäsentämisessä noudatettiin niin kutsuttua heikkoa prosessuaalista otetta, jossa organisaation tai julkisyhteisön oletettiin pysyvän substantiaaliselta olemukseltaan suhteellisen identtisenä, mutta samalla muutoksen etenmisen tulkinnassa ja esittämisessä nojauduttiin subjektiivisempaan, kerronnalliseen otteeseen (Van de Ven \& Poole 2005). Noin 20:n vuoden pitkittäisaineisto jaettiin ajallisesti erillisiin vaiheisiin, jotka ilmentävät vallitsevan institutionaalisen pilarin tai logiikan muuttumista. Näitä vaiheita identifioitiin kolme kappaletta. Kunkin vaiheen institutionaalisia merkityksiä ja viitekehyksiä pyrittiin tämän jälkeen kuvailemaan laadullisesti eri aineistolähteitä hyväksi käyttäen.

\section{TYÖSUHDEKÄYTÄNTÖJEN INSTITUTIONAALINEN MUUTOS SUOMEN ORTODOKSISESSA KIRKOSSA}

\section{Vuoden 2006 lakimuutos ja sen liepeillä käyty keskustelu}

Uuden ortodoksisen kirkkolain valmistelu aloitettiin 2002. Kirkon piirissä koettiin, että voimassa oleva säännöstö oli hallinnollisesti raskas ja osin epäselvä. Esimerkiksi kirkon piispa korosti seminaariesityksessään, että hallintoa tulisi tarkastella ensisijaisesti kirkko-organisaation hengellisen perustehtävän tai mission toteuttajana (Räntila 2002, 6). Toisessa puheenvuorossa kirkon projektipäällikkö kuvaa yleisellä tasolla sitä, miten julkishallinto on muuttunut markkinavoimien esiin nousun ja moniarvoisuuden myötä avoimemmaksi ja joustavammaksi (Härkönen, 2005). Kirjoittaja perään kuuluttaa vanhakantaisen byrokratian purkamista verkostomaisen toimintakulttuurin mahdollistamiseksi myös ortodoksikirkossa. Hän esittää, että ottamalla käyttöön laajemmat vapaaehtoisvoimat, kirkko voisi oppia asettamaan tulevaisuuden suunnittelun perustaksi asiakaslähtöisyyden. Hallintokoneiston tai virkamiespapiston sijaan toimintaa tulisi ohjata kirkon asiakkaiden eli seurakuntien jäsenten tarpeet ja toiveet. Myös kirkon keskushallinnossa toiminut asiantuntija korosti asiakaspalvelun roolia hallinto-organisaation tarkastelussa ja esitti, että hallintoa tulisi kehittää joustavammaksi ja käytännönläheisemmäksi (Räntilä 2006). Lainmuutos nähtiin keinoksi tehdä tilaa kevyemmälle hallintomenettelylle osana toiminnan tulevaisuussuuntautunutta kehittämistä (Lindström 2005).

Valmistelutyön seurauksena syntyneen hallituksen esityksen mukaan (HE 59/2006) lainmuutoksella tavoiteltiin kirkon sisäisen hallintaja päätöksentekovallan kasvattamista korostamalla kirkon aiempaa autonomisempaa roolia suhteessa valtioon. Toisaalta esityksessä ehdotettiin, että ortodoksinen kirkko säilyttäisi edelleen julkisyhteisöllisen asemansa. Henkilöstöhallinnon osalta uuden lain päämääräksi kuvattiin aiempaa parempien osallistumismahdollisuuksien ja tasavertaisemman työntekijäaseman takaaminen.

Työsuhdekäytäntöjen näkökulmasta merkittävin uuteen lakiin ehdotettu muutos liittyy kirkon henkilöstön siirtymiseen virkasuhteesta työsopimussuhteeseen. Virkamiesjärjestelmä katsotaan hallituksen esityksessä säätelyltään raskaaksi ja vanhanaikaiseksi. Työsuhdejärjestelmään siirtymisen myötä henkilöstö voisi osallistua aiempaa paremmin työehdoista käytäviin neuvotteluihin, mikä edistäisi henkilöstön koettua osallistumista ja työmotivaatiota (HE 59/ 2006, 12-13). Lisäksi esityksessä todetaan, että virka- ja työsopimussuhteen oikeudelliset muodot ovat siinä määrin lähentynyt toisiaan, etteivät näiden kahden palvelustyypin väliset erot 
ole enää merkittäviä käytännön työelämän kannalta. Valiokuntakäsittelyn jälkeen uudessa laissa vahvistettiin ortodoksisen kirkon siirtyminen työsuhdemuotoon.

Vuoden 2002-2006 kehityksestä voidaan yleisesti todeta, että lakimuutoksen valmistelun aikana kirkon piirissä esitettiin pitkälti uuden julkisjohtamisen mukaisia näkemyksiä hallinnon keventämisen ja avoimemman toimintakulttuurin puolesta. Hallintoa pyrittiin tarkastelemaan asiakaspalvelun näkökulmasta kirkon perustehtävän toteuttamisen välineenä, mikä puolestaan edellyttäisi tiiviin valtioyhteyden purkamista ja hierarkkisten tasojen vähentämistä. Toisaalta nähtiin, että vallitseva byrokraattinen virkamieskulttuuri esti sellaisen laajemman verkostomaisen toimintatavan, jossa organisaation vapaaehtoisresursseja voitaisiin käyttää tehokkaammin toiminnan vahvistamiseksi. Kannanotoissa esitetyt mielikuvat organisaatiosta seurasivat uuden julkisjohtamisen käsitteellisiä malleja, joissa julkiset yhteisöt kuvataan markkinaympäristössä asiakasta palvelevina toimijoina, joiden tarkoituksenmukaisen toiminnan ehtona on laajempi kosketuspinta verkostoihin ja kansalaisyhteiskuntaan. Vaikka keskustelussa ei suoraan käsitelty virkasuhteen ja työsuhteen välisiä eroja, kriittinen suhtautuminen virkamiesmalliin tarjosi välillisesti tukea ajatukselle työsopimussuhteisiin siirtymiselle osana hallinnon muutosta.

Vuonna 2006 hyväksytyn lakimuutoksen (Laki ortodoksisesta kirkosta 985/2006) sisällössä heijastuivat monet julkisjohtamisen paradigmasta polveutuvat näkemykset vahvemmasta sisäisestä autonomiasta, hallinnon keventämisestä ja virkamiesjärjestelmän purkamisesta. Ortodoksinen kirkko sai itsenäistä norminantovaltaa ja sen päätöksentekojärjestelmää irrotettiin valtiosta, vaikka samalla kirkkokunta kuitenkin säilytti julkisyhteisöllisen aseman. Päätös henkilöstön siirtämiseksi virkasuhteista työsuhteisiin ei ollut täysin kiistatonta, sillä lainvalmistelun yhteydessä esitettiin myös virkasuhdemuodossa pysymistä kannattavia argumentteja (HaVM 20/2006, 4). Työsopimussuhteiden puolesta kuitenkin puhui se, että muutoksella voitaisiin kohentaa työntekijöiden osallistumismahdollisuuksia ja rakentaa joustavampia työehtomalleja.

Professionaalisen logiikan näkökulmasta lakimuutos nähtiin pääosin positiivisena. Sisäisen autonomian vahvistamisen nähtiin mahdollista- van aiempaa paremmin ortodoksisen dogmien ja kanonisen perinteen toteuttamisen hengellisessä työssä (Suomen ortodoksinen kirkkohallitus 2006; Helsingin Metropoliitta 2006). Pappeuden asema kirkkoyhteisössä määrittyi pääpiirteissään entisen kaltaisesti uudessa laissa ja muun muassa muodolliset pätevyysvaatimukset säilyivät muuttumattomina. Pappeuden profession perspektiivistä käsin irtautuminen valtiovallasta ja virkamiesjärjestelmän purkaminen antoivat tilaa pappien varsinaisen hengellisen palvelutehtävän suorittamiselle ortodoksisen perinteen ja kanonisen hallintamallin mukaisesti (Nyström 2008; Heikkilä 2007).

\section{Työsuhdekäytännöt institutionaalisen muutoksen yhteydessä 2007-2014}

Hallinnon muutos jatkui uuden lain voimaantulon jälkeen byrokratiaa keventämään pyrkivillä aloitteilla. Esimerkiksi vuonna 2008 kirkko julkaisi mietinnön (Ortodoksisen kirkon PTS työryhmä 2008) hallinnon pitkän tähtäimen kehittämisestä, minkä pohjalta kirkolliskokous vahvisti yhteisön ensimmäisen muodollisen"strategian" vuosille 2010-2015. Mietinnössä tunnistetaan uuden lain tarjoama mahdollisuus keventää organisatorista säätelyä. Pitkän tähtäimen tavoitteeksi asetetaan hallinnon yksinkertaistaminen, ja voimavarojen vapauttaminen ydinprosesseihin, eli hengelliseen työhön. Henkilöstön panosta pyrittiin tukemaan laadukkaalla johtamisella ja uudistuksilla, joiden tarkoituksena on auttaa papistoa mahdollistamaan asiakkaiden tai seurakuntalaisten kirkollinen osallistuminen. Työntekijöitä koetettiin myös sitouttaa kirkon missioon ja visioon tavalla, joka edesauttaisi strategian menestyksekästä toteuttamista.

Oikeuskäytäntö osoitti ortodoksisen kirkon toimineen uuden lain ympäristössä asianmukaisella tavalla. Kirkko selvisi voittajana ensimmäisissä tuomioistuimissa käsitellyissä, työsuhteisiin liittyvissä riitatapauksissa (Tuppurainen 2008; Paananen 2008). Näkyvimpänä tapauksena julkisuuteen nousi pappi Mitro Revon määrääminen toimituskieltoon vaaliehdokkuuden vuoksi vuonna 2009 (Yle Uutiset 2009). Revon tekemä hallintokantelu päättyi SOK:n eduksi, kun korkein hallinto-oikeus vahvisti piispainkokouksen tekemän päätöksen laillisuuden (Mölsä 2009). 
Myös kirkon omissa lehdissä käydyssä keskustelussa painotettiin hallinnon kehittämisen tarpeellisuutta uuden julkisjohtamisen paradigmaa myötäillen. Eräs kolumnisti esimerkiksi perään kuulutti seurakunnan asiakkaiden tai jäsenten vahvempaa roolia päätöksenteossa. Kirjoittajan mukaan seurakuntatasolla tarvitaan perinteisen hallinnon uudelleen suuntaamista aiempaa selkeämmin varsinaisen hengellisen työn tukemiseen (Kallinen 2010). Toinen kirjoittaja taas pelkäsi näkymää, jossa seurakunnista tulee uskonnollisten tarpeiden virastoja tilanteessa, jossa tavoitteena tulisi olla välittömiin kohtaamisiin perustuvat yhteisöt. Seurakunnan työntekijöiden tehtävänä pitäisi olla kirkon jäsenten aktivointi ja innostaminen, kirjoittaja korostaa (Huttunen 2010). Toinen kolumnisti esitti, että henkilöstön näkökulmasta siirtyminen asiakaslähtöiseen toimintamalliin merkitsee joustavuutta myös omien työtehtävien suhteen. Hänen mukaansa on ymmärrettävä, että hallinto on palvelua, jonka on toteuduttava siellä, missä sitä tarvitaan (Härkönen 2010).

Samalla on kuitenkin havaittavissa puheenvuoroja, joissa aletaan painottaa byrokraattiselle logiikalle ominaisia näkökulmia, kuten tasapuolisuutta, oikeudenmukaisuutta ja objektiivisuutta. Erään kirkkoherran mukaan regulatiivinen muutos oli toteutunut tavalla, joka oli vain näennäisesti kanonisen perinteen ja demokratian mukainen; sen sijaan todellisuudessa seurauksena oli ollut vallan keskittäminen ilman vastuuta tai hallinnon kohteiden oikeusturvaa (Huurinainen 2010). Uuden lain seuraukset näkyivät kirjoittajien mukaan erityisesti työsuhdekäytännöissä. Esimerkiksi uuden työsuhdejärjestelmän mukaisen palkkausjärjestelmän ei nähty kohtelevan tasapuolisesti eri yksiköissä toimivia pappeja (Räntilä 2011). Henkilöstöhallintoa ei myöskään pidetty johdonmukaisena, vaan rekrytointien koettiin paikoin tapahtuvan sopivuutta pätevyyden sijaan korostaen (Hariton 2010). Julkisuudessa käytiin lisäksi periaatteellisempaa keskustelua (Räikkä 2012) kaanonien ja Suomen lakien välisestä suhteesta pappien työsuhdekysymyksissä (Korpela 2012), erityisesti perusoikeuksien toteutumisen näkökulmasta (Purmonen 2012).

Aineiston perusteella voidaan kuitenkin todeta, että ajanjaksolla kirkon parissa edelleen hyväksyttiin yleisesti uuden julkisjohtamisen mukainen näkemys hallinnon organisoimisen tavoitteista. Sekä nykytilaa puolustavissa että siihen kriittisesti suhtautuneissa puheenvuoroissa nähtiin tärkeäksi hengellisen työn vapauttaminen liiallisesta byrokratiasta, mihin usein liitettiin mielikuva kirkon ihanteellisesta organisaatiosta joustavana, asiakassuuntautuneena järjestelmänä. Henkilöstöhallinnossa korostettiin tarvetta lähestyä kirkon toimenkuvia strategian muutoksien myötä muovautuvina tehtävinä, joiden pääasiallinen tavoite on tukea yhteisön hengellisten palveluprosessien vahvistamista ja uudistamista. Tuomioistuimet vahvistivat ratkaisuissaan kirkon uusien käytäntöjen lainmukaisuuden tai oikeudellisen hyväksyttävyyden, mikä osaltaan legitimoi uuden julkisjohtamisen paradigmaa regulatiivisen pilarin parissa.

Kaudella nousi kuitenkin esiin myös näkemyksiä, joissa kyseenalaistettiin uuden lain esittelemän johtamisparadigman oikeudenmukaisuus ja tasapuolisuus. Nämä byrokraattisen logiikan mukaiset kommentit koskettivat ennen muuta kanonisen hallintomallin ja maallisen oikeusetiikan välistä suhdetta. Puheenvuoroissa esitettiin, kuinka uskonnollista autonomiaa edustavien kanonisten perinteiden soveltaminen saattoi uhata regulatiivisen pilarin edustamia oikeusturvan ja tasapuolisen kohtelun periaatteita. Byrokraattisen logiikan edustama kritiikki tuli pääasiassa seurakuntien papiston suunnalta.

\section{Työsuhdekäytäntöjen määrittyminen vuosina 2015-2020}

Vuonna 2014 SOK:n kirkolliskokouksessa kirkolle hyväksyttiin uusi strategia vuosille 20162020 (Suomen ortodoksinen kirkko 2015). Suunnitelmassa korostetaan muun muassa tarvetta kartoittaa seurakuntalaisten tai asiakkaiden tarpeita ja odotuksia, ja uudistaa toimintakulttuuria sekä vahvistaa palvelevaa asennetta työyhteisöissä tavoitteiden saavuttamiseksi. Kirkolliskokouksen käsittelyssä "strategia" -sanan käytöstä kuitenkin luovuttiin, koska strategian nähtiin käsitteenä viittaavan ensisijaisesti liike-elämän ja sodankäynnin elämänalueille (Suomen ortodoksisen kirkon kirkolliskokous, 2015; 18). Strategian nimeksi muutettiinkin kirkolliskokouksen päätöksellä uskonnolliselle yhteisölle paremmin sopiva "tavoite- ja toimintasuunnitelma”. 
Uuden toimintasuunnitelman siivittämänä käynnistettiin myös hallinnon uudistamisen prosessi, jonka eräänä taustavaikuttimena nähtiin tiukentuneen taloustilanteen ohella seurakunnissa kohdatut hallinnon asianmukaisen toteuttamisen puutteet ja ongelmat (Suomen ortodoksinen kirkko 2017). Hallinnonuudistuksen yhteydessä tilattiin useita oikeudellisia asiantuntijalausuntoja, jotka painottivat kirkon hallinnolle julkisyhteisönä asetettuja oikeudellisia ja prosessieettisiä edellytyksiä, mutta myös työnantaja-asemaan liittyviä työlainsäädännöllisiä ja yhdenvertaisuusvaatimuksia (Paso 2015; Palsola 2018). Kirkollishallitus korostikin omassa välilausunnossaan, että mahdollisten hallinnon rakennemuutosten yhteydessä on tiedostettava se, että SOK:ta sitovat edelleen hallintolain ja julkisuuslain määräykset, sekä näiden lisäksi lukuisat muut laintasoiset säädökset, mukaan lukien työsuhdekäytäntöä määrittävät työoikeudelliset normit ja tasa-arvonäkökulmat. Hallinnon muodolliseen sääntelyyn liittyvien haasteiden vuoksi hallinnonuudistuksen erääksi keskeiseksi tavoitteeksi asetettiin seurakuntien koon kasvattaminen riittävien hallintovoimavarojen varmistamiseksi. Lisäksi päämääränä oli työsuhdekäytäntöjen yhtenäistäminen keskittämällä henkilöstöhallinnollista johtamista koko kirkkokunnan tasolle (Suomen ortodoksinen kirkko 2017).

Hallintoreformin käynnistyttyä alettiin samaan aikaan julkisuudessa raportoida lisääntyvästi ortodoksisten seurakuntien ja niiden pappien välisistä työsuhdekiistoista ja näihin liittyneistä oikeudenkäynneistä. Suurta näkyvyyttä sai muun muassa tapaus, jossa Euroopan parlamentin jäsenyydestä kirkon pappistehtäviin palannut Mitro Repo irtisanottiin papille sopimattoman käytöksen ja työtehtävien laiminlyönnin vuoksi (mm. Vaalisto 2016). Repo nosti haasteen seurakuntaa vastaan käräjäoikeudessa, ja media seurasi tiiviisti kannetta seurannutta oikeusprosessia (esim. Thynell 2017; Mäkinen 2018).

Käräjäoikeus katsoi, että vaikka Repo oli todistettavasti käyttäytynyt vastoin kirkon säädöksiä, työsuhteen irtisanomista ei ollut toteutettu asianmukaisesti seurakunnan toimesta. Papin olisi tullut tietää tarkemmin ne sopimattoman käytöksen ja työtehtävien laiminlyönnin tilanteet, joista häntä oli varoitettu. Käräjäoikeus katsoi ratkaisussaan, ettei seurakunnalla ollut työsopimuslain edellyttämää perustetta purkaa työsuhdetta. Toisaalta oikeus totesi, että pappi oli omalla käytöksellään myötävaikuttanut irtisanomisprosessin käynnistymiseen, ja madalsi tämän vuoksi seurakunnalle tuomittua korvaussummaa (Helsingin KO, L 16/58576).

Kirkko hävisi myös kaksi muuta lainvoiman saanutta oikeustapausta, joilla oli ennakkopäätöksellistä merkitystä. Ensimmäisessä kysymys oli kirkkoherran toimituskieltoon määräämisen vaikutuksesta määräaikaiseen palkanmaksun keskeyttämiseen ja työnteon katkaisemiseen (Itä-Suomen HO, S 18/233). Kirkko esitti käräjäoikeusvaiheen todistelussa, että kirkon sisäisen järjestyksen mukaisesti asetettu toimituskielto merkitsisi samalla papin estymistä kaikesta seurakuntatyöstä (L16-14913). Hovioikeusvaiheen käsittelyssä kuitenkin selvisi, ettei toimituskiellon kattavasta seurauksesta pappeuteen kuitenkaan ollut säädetty kirkkolaissa, vaan työsuhteen katkaisemista tarkasteltiin lain mukaan oikeudellisesti pelkästään työsopimuslain mukaisesti. Seurakunta tuomittiin maksamaan korvauksia työsopimuslain velvollisuuksien rikkomisesta.

Toisessa tapauksessa kyse oli määräaikaisen työsuhteen katkeamisesta ja myöhemmästä työhönottokiellosta. Papin tehtävän avauduttua seurakunta ei ollut ryhtynyt täyttämään tehtävää, vaan jatkoi sen hoitamista määräaikaisilla työsuhteilla. Monisyinen riita tiivistyi kysymykseen siitä, oliko seurakunnalla ja hiippakunnalla oikeus valita sopivaksi katsomansa henkilö määräaikaiseen toimeen, ja toisaalta, mihin saakka kanoninen päätöksentekovalta ulottuu työsuhteiden järjestämisessä ja työn johtamisessa. Hovioikeus katsoi ratkaisussaan, että kyseisen papin työsuhdejärjestelyissä oli toimittu tasaarvolain ja yhdenvertaisuuslain vastaisesti, ja että määräaikaisen työsuhteen tekemiselle ei ollut perusteita (Helsingin HO S 18/1122).

Hävityt oikeusjutut herättivät kiinnostusta mediassa (Kilpeläinen 2019; Ojanperä 2018), ja alkoivat yhdessä muiden raportoitujen hallinnon ja toiminnan epäselvyyksien ja kiistojen (mm. Krautsuk 2018) kanssa vaikutta SOK:n julkikuvaan. Entistä laajempaan tietoisuuteen kirkon hallinnon ongelmat levisivät vuoden 2020 toukokuussa, kun verkkojulkaisu Long Play julkaisi laajan artikkelin SOK:n talous- ja työsuhdekäytännöistä (Salovaara 2020). Artikkelissa käsiteltiin edellä esiteltyjä työsuhderiitoja, mutta 
myös taloushallinnon epäselvyyksiä. Jutussa kiinnitettiin huomiota kirkon johtamisjärjestelmään, johon oli artikkelin mukaan lainmuutoksen jälkeisenä aikana muodostunut toiminnan valvontaan ja sisäisiin vastuusuhteisiin liittyviä puutteita ja epäselvyyksiä. Long Play:n artikkelin väitteet, eritoten viittaukset taloudellisiin epäselvyyksiin, nousivat median etusivun uutiseksi (esim. Mattila 2020). SOK:n hallinnon kiistanalaisia kysymyksiä käsiteltiin laajasti myös kirkollisessa mediassa (Toivanen 2020; Rytkönen 2020) ja valtalehtien mielipidepalstoilla (Tolvanen 2020; Riikonen, Koponen \& Metso 2020).

Tuomioistuintapaukset alkoivat mediajulkisuuden rinnalla heijastua myös SOK:n sisäisissä keskusteluissa ja linjauksissa. Vuonna 2019 kirkollishallitus laati kirkon henkilöstöhallintoa ohjaavat rekrytointiperiaatteet (Suomen ortodoksinen kirkollishallitus, 2019). Periaatteissa käydään läpi pappeuteen ottamisen, pappina toimisen ja pappeuden menettämisen sääntöjä ja käytäntöjä kirkon uskonnollisen perinteen näkökulmasta, päähuomion ollessa tilanteissa, joissa pappi on toiminut epäasiallisesti. Yleisellä tasolla esitys muistuttaa siitä, että haastavat työsuhdetilanteet tulisi ratkaista siten, että päätöksissä huomioidaan se, miltä valittu toimintatapa näyttää jäsenten ja yhteiskunnan laajemmasta näkökulmasta käsin.

Vuonna 2020 kirkollishallitus puolestaan tilasi uuden selvityksen työsuhdekäytäntöjen oikeudellisen regulaation tulkinnasta (Tarukannel 2020). Tämä ulkopuolisen asiantuntijan laatima selvitys käsittelee seikkaperäisesti työsuhteita säätelevää maallista ja kanonista oikeutta SOK:n parissa. Asiantuntijan mukaan kirkon sisäiset järjestelyt eivät vapauta organisaatiota työoikeudellisesta vastuusta. Työsopimuslain lisäksi tasaarvo- ja yhdenvertaisuuslaki normittavat työsuhdekäytäntöjen laillista hyväksyttävyyttä. Asiantuntija suosittelee, että jatkossa kirkon tulisi jatkossa henkilöstövalintaprosesseissaan esittää avoimesti ansioiden ja tehtävään sopivuuden arvioinnin ja vertailun tulokset, minkä lisäksi kirkon olisi muun muassa perusteltava huolella tehtäviin ottamista edeltävät hallintopäätökset. Työsopimusten laadintaan ja määräaikaisten työsuhteiden perusteisiin tulisi myös paneutua aiempaa tarkemmin oikeudellisten ongelmien välttämiseksi.
Yllä mainittu Long Play:n artikkeli (Salovaara 2020) ja sen synnyttämä kirkollinen ja yhteiskunnallinen keskustelu asettivat painetta kirkon johdolle. Arkkipiispa vastasi viiveen jälkeen Long Play-artikkelin väitteisiin korostamalla hiljattain tehtyä työsuhdeselvitystä ja oikeuskäytännön myötä selkiytynyttä työlainsäädännön tulkintaa suhteessa kanoniseen oikeuteen (Long Play 2020). Kirkon verkkosivulla arkkipiispa puolestaan kommentoi kysymyksiä sanoen, että samalla kun kirkko on panostanut viime vuosikymmeninä hengelliseen työhön, on se jättänyt huomiotta hallinnon kehittämisen ja vahvistamisen (Arkkipiispa Leo 2020). Arkkipiispan mukaan SOK:n hengellinen elämä kuitenkin edellyttää, että kirkko vastaa julkisyhteisönä sille asetettuihin hallinnon asianmukaisuuden vaatimuksiin. Oleellista hänen mukaansa on se, että kirkko noudattaa lakia sekä työelämän normeja ja sääntöjä.

Arkkipiispan vanavedessä tarvetta hallintoosaamisen vahvistamiseen korostettiin myös kahden hiippakunnan kirkkoherrojen julkaisemissa tiedotteissa (Järvelin \& Lampropoulos 2020; Kiiveri ym. 2020). Kirkkoherrat totesivat, että hallinnossa ja työsuhdekäytännöissä on tehty virheitä, jotka on kuitenkin oikeusvaltion perinteiden tavoin käsitelty asianmukaisesti tuomioistuimissa. Keskeistä SOK:n hallinnon kehittämisessä oli kirjoittajien mielestä vastuuhenkilöiden johtamisosaamisen vahvistaminen koulutuksen ja hallintokulttuurin muuttamisen kautta. Hallinnon asianmukainen toteuttaminen vaatii heidän mielestään uutta tietämystä monimutkaistuvassa säätely-ympäristössä. Kirkon hallinto ei ole hengellisen työn este, vaan muodostaa kirkkoherrojen mukaan keskeisen uskonnollista perustehtävää tukevan alueen, jota on harjoitettava julkisyhteisöltä edellytettävällä oikeudellisella asianmukaisuudella.

Yhteenvetona voidaan todeta, että jakson kuluessa kirkon hallinnon ja työsuhdekäytäntöjen muovautumiseen alkoivat entistä selvemmin vaikuttaa oikeudelliset ja hallintoeettiset näkökannat. Hallinnon uudistamisen yhteydessä kirkko ryhtyi ottamaan etäisyyttä uuden julkisjohtamisen käyttämästä liiketaloudellisesta strategiadiskurssista korostamalla SOK:n aatteellista ja julkisoikeudellista identiteettiä. Hallintouudistuksessa nousivat myös aiempaa vahvemmin esiin oikeudelliset näkökulmat, jotka viivästivät 
byrokratian keventämiseen tähdänneitä hankkeita.

Työsuhdekäytäntöjen muovautumisessa ratkaisevaan rooliin asettuivat tuomioistuinten ratkaisut useissa työoikeudellisissa kiistoissa. Seurakunnat hävisivät kolme merkittävää ennakkotapauksellista riitaa, joista myös raportoitiin laajasti julkisuudessa. Vaikka kirkon edustajat pitivät tuomioistuinten ratkaisuja kanonisen oikeuden ja kirkon erillisaseman näkökulmasta pitkälti puutteellisina tai virheellisinä (Helsingin ortodoksinen seurakunta 2018; Helsingin ortodoksinen seurakunta 2020; Heikkilä 2009), alkoi SOK selvittää koko kirkkokunnan tasolla työsuhdekäytäntöihin liittyviä lainsäädännöllisiä ongelmia asiantuntijavoimin. Työoikeudellisiin kysymyksiin keskittynyt laajempi raportti päätyi korostamaan maallisen työ- ja tasa-arvolainsäädännön merkitystä suhteessa pappeuden professiota määrittävään kanoniseen oikeuteen (Tarukannel 2020).

Kirkon kielteinen asennoituminen työsuhteita koskevan sääntelyn laajaan tulkintaan kirkon henkilöstökäytännöissä murtui vuoden 2020 kevätkesällä käydyn keskustelun seurauksena. Kimmokkeena toimi Long Play-lehden artikkeli, joka kirvoitti joukon kriittisiä puheenvuoroja SOK:n hallinnon ja työsuhdekäytäntöjen oikeudellisesta ja hallintoeettisestä asianmukaisuudesta. Kirkon johto tunnusti, että sillä on ollut ongelmia työsuhteita koskevien normien hallinnassa ja henkilöstöjohtamisen toteuttamisen lainmukaisuudessa. Hyvän hallinnon katsottiin nyt kuuluvan oleellisesti kirkon toiminnan ytimeen hengellisen työn rinnalla sen sijaan, että hallintoa ja työsuhdekäytäntöjä olisi tarkasteltu aiempaan tapaan välineellisesti uskonnollisen toiminnan mahdollistajana tai esteenä. Kirkko nojautui vahvasti kanonisen oikeuden rakenteisiin ja arvoihin puolustaessaan työlainsäädännöllisesti poikkeavia käytäntöjään, mutta oikeudellisten tapausten, asiantuntija-arvioiden ja kriittisen mediajulkisuuden paine johti lopulta pappeuden profession legitimiteetin ratkaisevaan heikentymiseen kirkon piirissä. Jakson lopulla regulatiivisen pilarin korostamat muodolliset säännöt ja toiminnan lainmukaisuus olivat nousseet työsuhdekäytäntöjä ensisijaisesti määrittäviksi institutionaalisiksi voimiksi.

\section{JOHTOPÄÄTÖKSET JA KESKUSTELU}

Tämän artikkelin tavoitteena oli lisätä ymmärrystä työsuhdekäytäntöjen institutionaalisesta muutoksesta hallinnon uudistuksen yhteydessä. Institutionalisoitumisen prosesseja analysoitiin Scott:in (2008a) esittelemästä kolmen pilarin dynaamisesta viitekehyksestä (Hoffman 1999) käsin, tarkoituksena nostaa esiin aiemmin sivuutetun regulatiivisen pilarin rooli uuden julkisjohtamisen paradigman laukaisemien muutosprosessien toteutumisessa. Tapaustutkimuksessa kuvattiin Suomen ortodoksisen kirkon työsuhdekäytäntöjen muovautumista vuosina 2002-2020.

Tiivistäen voidaan todeta, että Suomen ortodoksisen kirkon tapaus ilmentää kehityskulkua, jossa työsuhdekäytäntöjen määrittyminen muuttuu asteittain uuden julkisjohtamisen mukaisista painotuksista ensin profession normeja mukailevia korostuksia kohden, ja edelleen viime vaiheessa byrokraattisen logiikan kaltaisten regulatiivisen ja oikeudellisen asianmukaisuuden periaatteiden suuntaan. Muutoksessa voidaan erottaa kolme institutionaalisten pilarien ja logiikkojen vaihetta:

1) Ensivaiheessa uuden julkisjohtamisen logiikka vaikuttaa vahvasti hallinnon ja työsuhdekäytäntöjen muovautumiseen. Kirkon asemaa ja toimintaa säätelevän lain uudistuksessa vaikuttavat taustalla uuden julkisjohtamisen näkökulmat, kuten joustavuus ja asiakaslähtöisyys. Konkreettisesti uudet organisoinnin kognitiiviset skeemat ja symboliset mallit ilmenevät työsuhteiden alueella siirtymisenä työsopimussuhteisiin kirkon henkilöstön keskuudessa. Pappeuden professio tukee tässä vaiheessa uuden julkisjohtamisen näkökohtia.

2) Toisessa vaiheessa tavoitteena on edelleen hallinnon keventäminen ja työsuhdekäytäntöjen joustavoittaminen. Työsuhteita tarkasteltaessa taustanäkemyksenä on strategisen vision ohjaama toimintakokonaisuus, jonka parissa työskentelee strategiaan sitoutuneita työntekijöitä. Samaan aikaan alkaa kirkon kentältä nousta toiminnan tasapuolisuutta ja oikeudenmukaisuutta kriittisesti arvioivia ääniä. Sekä nykytilaa puolustavissa että siihen kriittisesti suhtautuneissa puheenvuoroissa nähtiin kui- 
tenkin tärkeänä hengellisen työn vapauttaminen liiallisesta byrokratiasta.

3) Kolmannessa vaiheessa työsuhdekäytäntöjen oikeudellinen asianmukaisuus nousee valokeilaan seurakuntien häviämien riitajuttujen myötä. Uuden julkisjohtamisen mukaiset aspektit katoavat pitkälti näkyvistä regulatiivisen ja normatiivisen pilarin alkaessa käydä keskinäistä kamppailuaan työsuhdekäytäntöjen määrittymisestä. Kirkon edustajat vetoavat kanonisen oikeuden periaatteisiin pappien työsuhteissa, kun taas oikeusasteet ja asiantuntijat rajaavat työsuhdekysymykset tiiviisti maallisen työja tasa-arvolainsäädännön piiriin kuuluvaksi. Hallintoa käsittelevä kriittinen mediajulkisuus kääntää kamppailun regulatiivisen pilarin voitoksi. Kirkko tunnustaa, että sen on jatkossa varmistettava, että työsuhteiden hallinnassa noudatetaan soveltuvia lakeja ja säädöksiä.

Yleisemmällä tasolla tapaustutkimus osoittaa, miten regulatiivisen pilarin sisällyttäminen institutionaalisen muutoksen viitekehykseen mahdollistaa rikkaamman kuvauksen kuin jos prosesseja olisi tarkasteltu pelkästään kulttuuriskognitiivisen ja normatiivisen pilarin keskinäisenä dynamiikkana (Peton \& Pezé 2014; Hoffman 1999). Ortodoksisen kirkon tapauksessa uuden julkisjohtamisen ja pappeuden profession logiikkojen väliset suhteet eivät yksinään kykene selittämään työsuhdekäytäntöjen muovautumista. Pappeuden professio tukee ensi vaiheessa uuden julkisjohtamisen mukaista joustavuuden ja strategiaohjautuvuuden ideaa, kunnes se myöhemmissä vaiheessa irtautuu yhteydestä uuteen julkisjohtamiseen, ja ottaa itsenäisen roolin työsuhdekäytäntöjen määrittäjänä ja regulatiivisen pilarin muodollisten sääntöjen ja normien vastinparina. Kolmiosainen institutionaalisten pilarien viitekehys mahdollistaa hallinnon institutionaalisen muutoksen ja pysyvyyden hienovaraisemman tulkinnan (Barzelay \& Gallego 2006; Christensen \& Lægreid 2011).

Henkilöstöjohtamisen tutkimuksen alueella artikkelin kontribuutiona on tuoda esille työsuhdekäytäntöihin kohdistuvat vanhemmat tai perinteisemmät institutionaaliset voimat. Kulttuuris-kognitiiviset mallit modernista henkilös- töjohtamisesta ovat viime vuosikymmeninä korostaneet työsuhdekysymysten tarkastelua organisatoristen strategioiden toteuttamisen ja kehittämisen näkökulmasta. Työvoiman käytössä on korostettu määrällistä ja laadullista joustavuutta. Julkisyhteisöissä nämä uuden julkisjohtamisen doktriinia myötäilevät "strategisen henkilöstövoimavarojen johtamisen" ideat ja viitekehykset ovat usein ilmenneet irtautumisena perinteisestä byrokraattisesta virkasuhdemallista (Bach 2019; Bach \& Kessler 2019; Brown 2004).

Ortodoksisen kirkon tapaustutkimus kuitenkin osoittaa, miten virkasuhdekontekstista irrotettuun henkilöstöhallinnon kenttään kohdistuu edelleen kilpailevia institutionaalisia voimia (Beszter, Ackers \& Hislop 2015). Professionaalisen kulttuurin rinnalla työelämän suhteiden kokonaisuutta määrittää Suomessa monitahoinen työoikeudellinen järjestelmä, joka asettaa omia vaateita työsuhdekäytäntöjen tarkoituksenmukaisuudelle. Siirtymä virkasuhteista työsuhteisiin ei välttämättä tarkoita aiemman byrokraattisen logiikan korvautumista uuden julkisjohtamisen mukaisella strategisen joustavuuden periaatteella. Virkamiehen aiempi suojeltu asema muun muassa irtisanomistilanteissa toki heikentyy siirryttäessä työsopimussuhteiseen järjestelmään (Mäkinen 2009). Toisaalta samalla on hyvä huomata, että työsuhdeympäristössä työntekijöillä on velvollisuuksien ohella monia työ- ja yhdenvertaisuuslainsäädännöstä polveutuvia oikeuksia (Paanetoja 2015). Työsuhteisiin liittyvät kiistat ratkaistaan aiempaa useammin tuomioistuimessa, monitahoiseen oikeudelliseen normistoon nojautuen.

Kirkon edustajien argumentit kuvatuissa tuomioistuinkäsittelyissä kuitenkin viittaavat siihen, että yhteisön johto on olettanut uuden työsopimusympäristön antavan verraten vapaat kädet järjestellä työsuhteita organisaation tarpeen mukaan. Erään seurakunnan kirkkoherra esimerkiksi painotti hovioikeuden todistelussa tarvetta tarkastella henkilöstövoimavaroja joustavana kokonaisuutena, jota voitaisiin tarpeen mukaan osoittaa erityyppisiin tehtäviin (T1704-55_S18_1122). Hän myös katsoi, että hyvään organiaatiokansalaisuuteen kuuluu ilmoittaa etukäteen tulevista perhevapaista. Toinen pappi puolestaan kertoi, että muodollisen tehtäväkuvauksen sijaan papin työsuhde tulisi määritel- 
lä yleisenä seurakuntatoimena, jossa työn kohteet ja sisällöt vaihtelevat tilanteellisen tarpeen mukaan (T09-26-13_S 18_1122).

Työoikeudellisten näkökulmien sivuuttaminen vanhakantaiseen virkamiesajatteluun ja sitä sivuavaan hallintobyrokratiaan kuuluvana ajoi paradoksaalisesti kirkon tilanteeseen, jossa regulatiiviset paineet ajoivat äkillisesti professionormien ja joustavan henkilöstöjohtamisparadigman katsantokantojen ohi. Sitoutuminen uuden julkisjohtamisen organisaatiomalliin ja strategisen henkilöstöjohtamisen oletuksiin jätti julkisyhteisön institutionaalisen muutoksen "väärälle puolelle", puolustamaan lainvastaisiksi todettuja käytäntöjä. Tapaustutkimuksen analyysi tuo tältä osin esille julkisyhteisöjen parissa potentiaalisesti piilevän dualistisen ajattelutavan, jossa säädellyn virkamieskontekstin ja uuden työsuhdejärjestelmän välille ei kyetä identifioimaan monitahoista regulatiivista kenttää, jota määrittävät osapuolten erilaiset velvollisuudet ja oikeudet. Kaksinainen ajattelutapa saattaa altistaa julkisyhteisön ottamaan riskejä oikeudellisten kiistojen käsittelyssä.

Suomen ortodoksisen kirkon piirissä tehtyjä havaintoja olisi hedelmällistä tarkastella edelleen muissa julkisyhteisöissä. Esiteltyä Scott:in (2008a) institutionaalisten pilarien viitekehystä voisi käyttää hyväksi muiden organisaatioiden tai organisatoristen kenttien muutosprosessien kuvaamisessa. Esimerkiksi yliopistoissa on siirrytty ortodoksikirkon tavoin virkasuhteista työsopimussuhteisiin. Anekdootilliset havainnot

\section{LÄHTEET:}

Arkkipiispa Leo (2020) Hengellinen työ vaatii tuekseen hyvin hoidetun hallinnon. Helsingin ja koko Suomen arkkipiispa Leon kommentti mediassa viime aikoina käytyyn keskusteluun kirkon hallinnon puutteista. Suomen ortodoksinen kirkko. 25.5.2020. Haettu sivulta https://ort.fi/uutishuone/2020-05-25/hengellinen-tyo-vaatii-tuekseen-hyvin-hoidetun-hallinnon 18.9.2020

Bach, Stephen (2019). Human resource management in the public sector: new public management, responsive governance and the consequences of the economic crisis. Teoksessa: Adrian Wilkinson, Nick Bacon \& S. Snell viittaavat siihen, että myös korkeakoulusektorilla uuteen työsuhdejärjestelmään siirtymiseen on liittynyt oikeudellisia riitoja, tuomioistuinten ratkaisuja ja keskustelua yliopisto-organisaatioiden regulatiivisesta profiilista (esim. Hanska 2020; Helsingin Sanomat 2018; vrt. Kosonen, Pekkola \& Siekkinen 2018). Yliopistojen työsuhdekäytäntöjen kuvaaminen eri tasoilla tarjoaisi uutta ymmärrystä niistä mekanismeista, jotka liittyvät regulatiivisen pilarin rooliin institutionaalisissa prosesseissa; samoin kuin niistä riskeistä, joita työsuhdekysymysten oikeudellisten aspektien sivuuttaminen saattaa aiheuttaa organisaatioiden tai yhteisöjen legitimiteetille.

Laajemmasta hallintoteoreettisesta näkökulmasta käsin Scott:in (2008a) viitekehyksessään esiin nostaman regulatiivinen pilarin merkitystä voisi käsitellä suhteessa keskusteluun Weberin (1947) byrokratiakäsitteen tulkinnoista ja ilmenemismuodoista nykyorganisaatioissa. Esimerkiksi du Gay (2000) on esittänyt, että Weberin byrokratiamuotoa tulisi tulkita eettisestä perspektiivistä käsin hallinnollisena rationaliteettina tai mallina, jonka tavoitteena on tukea organisaatioiden ja julkisyhteisöjen jäsenten toiminnan tasapuolisuutta ja neutraaliutta. Jatkotutkimus voisi pohtia sitä, missä määrin byrokratian ymmärtäminen yleisemmin eräänä moraalisen eetoksen muotona voisi auttaa organisaatioita ja julkisyhteisöjä niiden pyrkimyksissä kohti vastuullista ja oikeudenmukaista toimintakulttuuria.

(Eds.), The SAGE handbook of human resource management (pp. 557-574). London: SAGE Publications Ltd https://doi.org/10.4135/9781529714852.n33

Bach, Stephen, \& Bordogna, Lorenzo (2011). Varieties of new public management or alternative models? The reform of public service employment relations in industrialized democracies. The International Journal of Human Resource Management, 22(11), 2281-2294. https://doi.org/10.1080/09585192.2011.584399

Bach, Stephen, \& Kessler, Ian (2007). HRM and the new public management. Teoksessa: Purcell, Peter, Storey, John \& Wright, Patrick (Eds.), The 
Oxford handbook of human resource management. Oxford: Oxford University Press. https://doi.org/10.4135/9781529714852.n33

Barzelay, Michael, \& Gallego, Raquel (2006). From "new institutionalism" to "institutional processualism": advancing knowledge about public management policy change. Governance, 19(4), 531-557.

https://doi.org/10.1111/j.14680491.2006.00339.x

Beszter, Peter, Ackers, Peter, \& Hislop, Donald (2015). Understanding continuity in public sector HRM through neo-institutional theory: why national collective bargaining has survived in English local government. Human Resource Management Journal, 25(3), 364-381.

https://doi.org/10.1111/1748-8583.12051

Brown, Kerry (2004). Human resource management in the public sector. Public management review, 6(3), 303-309. https://doi.org/10.1080/1471903042000256501

Canhilal, S. Kubra, Lepori, Bendetto \& Seeber, Marco (2016). Decision-Making Power and Institutional Logic in Higher Education Institutions: A Comparative Analysis of European Universities. Research in the Sociology of Organizations, 45, 169-194.

https://doi.org/10.1108/S0733558X20150000045019

Caronna, Carol A. (2004). The misalignment of institutional "pillars": Consequences for the US health care field. Journal of Health and Social Behavior, Vol 45 (Extra Issue: Health and Health Care in the United States: Origins and Dynamics), 45-58.

Christensen, Tom, \& Lægreid, Per (2011). Complexity and hybrid public administrationtheoretical and empirical challenges. Public organization review, 11(4), 407-423. https://doi.org/10.1007/s11115-010-0141-4

Colley, Linda, McCourt, Willy, \& Waterhouse, Jennifer (2012). Hybrids and contradictions: Human resource management in the contemporary public sector. International Journal of Public Administration, 35(8), 507-512. https://doi.org/10.1080/01900692.2012.687958

DiMaggio, Paul J., \& Powell, Walter W. (1983). The iron cage revisited: Institutional isomorphism and collective rationality in organizational fields. American sociological review, 147-160. https://doi.org/10.2307/2095101

Dobbin, Frank, Sutton, John R., Meyer, John W., \& Scott, Richard (1993). Equal opportunity law and the construction of internal labor markets. American journal of Sociology, 99(2), 396-427. https://doi.org/10.1086/230269
Edelman, Lauren B., Uggen, Christopher, \& Erlanger, Howard S. (1999). The endogeneity of legal regulation: Grievance procedures as rational myth. American Journal of Sociology, 105(2), 406-54.

https://doi.org/10.1086/210316

Gannon, Thomas M. (1971). Priest/minister: Profession or non-profession?. Review of Religious Research, 66-79.

https://doi.org/10.2307/3510079

Hanska, Jari (2020) Tampereen yliopisto kätki rehtorihakijoiden paperit - neuvoi hakijaa oman hakemuksen salaamisessa. Suomen Kuvalehti, 18.2.2020. Haettu sivulta

https://suomenkuvalehti.fi/jutut/kotimaa/tampereen-yliopisto-katki-rehtorihakijoiden-paperit-neuvoi-hakijaa-oman-hakemuksen-salaamisessa/ 18.9.2020

Hariton (Isä Hariton) (2010) Kuinka kirkkoa päivitetään. Analogi,3/2010; 6-8.

HaVM 20/2006. Hallintovaliokunnan mietintö: Hallituksen esitys laiksi ortodoksisesta kirkosta 59/2006. 12.10.2006

HE 7/2009. Hallituksen esitys Eduskunnalle yliopistolaiksi ja siihen liittyviksi laeiksi. 20.2.2009.

HE 59/2006. Hallituksen esitys Eduskunnalle laiksi ortodoksisesta kirkosta. Ilmoitettu annetuksi Eduskunnalle 19.5.2006

Heikkilä, Jelisei (2007) Selkeyttä lainsäädäntöön. Ortodoksiviesti 1/2007; 8-9.

Heikkilä, Jelisei (2020) Kanonisia havaintoja Suomen ortodoksisen kirkkohallituksen 19.2.2020 tekemän päätöksen edellyttämää asiantuntijaselvitykseen. 30.5.2020. Haettu sivulta https://ort.fi/sites/default/files/2020-06/ Kanonisia\%20havaintoja\%20asiantuntijalausuntoon\%2C\%20Heikkilä\%20Jelisei.pdf 18.9.2020

Helsingin metropoliitta (2006) Eduskunnan hallintovaliokunnan lausuntopyyntö: HE 59/2006 (Lausunto). 13.6.2006

Helsingin ortodoksinen seurakunta (2020) Ortodoksipapin työsuhdekiista: seurakunta ei hae valituslupaa KKO:lta. 19.2.2020. Haettu sivulta https://www.hos.fi/ortodoksipapin-tyosuhdekiista-seurakunta-ei-hae-valituslupaa-kkolta/ 18.9.2020

Helsingin ortodoksinen seurakunta (2018) Seurakunta tyytymätön käräjäoikeuden ratkaisuun Seurakunnanneuvosto päätti yksimielisesti valittaa käräjäoikeuden 2. maaliskuuta antamasta päätöksestä hovioikeuteen työsuhderiitaa koskevassa asiassa. 27.3.2018. Haettu sivulta https://www.hos.fi/seurakunta-tyytymaton-karajaoikeuden-ratkaisuun/ 18.9.2020 
Helsingin Sanomat (2018) Käräjäoikeus havaitsi syrjintää yliopistolla. Yksittäisellä alalla paikkoja on rajallinen määrä, joten niiden täyttämisen täytyy erityisen hyvin kestää ulkopuolinen kritiikki. Pääkirjoitus, 12.10.2018. Haettu sivulta https://www.hs.fi/paakirjoitukset/art2000005860810.html 18.9.2020

Herranen, Olli (2015). Uusi julkisjohtaminen ja valtion tuottavuusohjelman kova ydin. Hallinnon tutkimus, 34(1), 27-42.

Hirsch, Paul M. (1997). Review essay: Sociology without social structure: Neoinstitutional theory meets brave new world. American journal of sociology, 102(6), 1702-1723. https://doi.org/10.1086/231132

Hoffman, Andrew J. (1999). Institutional evolution and change: Environmentalism and the US chemical industry. Academy of management journal, 42(4), 351-371. https://doi.org/10.5465/257008

Huttunen, Heikki (2010) Seurakunnan jälleen löytäminen. Analogi 3/2010; 14-15.

Huurinainen, Leo (2010) Missä mennään, mitä tuleman pitää. Analogi 3/2010; 9-10.

Härkönen, Jyrki (2005) Virkamieskirkosta kohtauspaikaksi- kirkkokunta vai kirkko? Analogi, 5/2005; 10-11.

Härkönen, Jyrki (2010) Hallinto hengellisiin keskuksiin. Analogi 3/2010; 12-13

Järvelin, Tuomas \& Lampropoulos, Ioannios (2020) Avoimuus on avain! Joensuun ja Ilomantsin kirkkoherrojen seurakuntalähtöinen kommentti ajankohtaiseen hallintokeskusteluun. Suomen ortodoksinen kirkko. 3.6.2020. Haettu sivulta https://ort.fi/uutishuone/2020-06-03/avoimuus-avain 18.9.2020

Kaipiainen, Ari-Pekka (2012) Metropoliitta Ambrosius: "Piispalla ei ole yksinvaltiutta". Seurakuntalainen, 18.4.2012. Haettu sivulta https://www.seurakuntalainen.fi/uutiset/ metropoliitta-ambrosius-piispalla-ei-ole-yksinvaltiutta/ 18.9.2020

Kallinen, Kimmo (2010) Ajat muuttuvat, haasteet säilyvät. Analogi 3/2010; 19-20.

Kallio, Kirsi Maria, Kallio, Tomi, Tienari, Janne, \& Hyvönen, T. (2016). Ethos at stake: Performance management and academic work in universities. Human Relations, 69(3), 685-709. https://doi.org/10.1177/0018726715596802

Ketola, Kimmo (2008) Uskonnot Suomessa 2008. Käsikirja uskontoihin ja uskonnollistaustaisiin liikkeisiin. Kirkon tutkimuskeskuksen julkaisuja 102. Tampere: Kirkon tutkimuskeskus.
Kiiveri, Ville, Salminen, Markku, Tynkkynen, Timo \& Bergenstad, Jonas (2020) Kannamme vastuuta yhdessä. Helsingin ortodoksisen hiippakunnan kirkkoherrojen kannanotto ortodoksisen kirkon johtamisesta käytyyn keskusteluun. Suomen ortodoksinen kirkko. 1.6.2020. Haettu sivulta https://ort.fi/uutishuone/2020-06-01/ kannamme-vastuuta-yhdessa 18.9.2020

Kilpeläinen, Kia (2019) Ortodoksipappi jätettiin valitsematta virkaan isyysvapaan takia - seurakunta joutuu maksamaan yli 113000 euron jättikorvaukset. Iltalehti, 24.12.2019. Haettu sivulta https://www.iltalehti.fi/kotimaa/a/23ceac78bf65-455b-a877-a3a731623b93 18.9.2020

Korpela, Jukka (2012) Ortodoksiset kaanonit ovat ristiriidassa lakien kanssa. Helsingin Sanomat, 11.4.2012. Haettu sivulta https://www.hs.fi/mielipide/art2000004867284.html 18.9.2020

Koskinen, Ilpo, Alasuutari, Pertti. \& Peltonen, Tuomo (2005) Laadulliset menetelmät kauppatieteissä. Tampere: Vastapaino.

Kosonen, Jonna, Pekkola, Elias, \& Siekkinen, Taru (2018). Akateeminen arviointi rekrytoinneissa: henkilön vai pätevyyden arviointia. Tiedepolitiikka 43 (1): 55-57.

Krautsuk, Satu (2018) Ortodoksien kirkkoherra hukkasi kuitit, laiminlöi työnsä ja katosi maisemista - seurakuntalaiset joutuivat siivoamaan sotkut. Yle Uutiset, 13.2.2018. Haettu sivulta https://yle.fi/uutiset/3-10066111 18.9.2020

Kulla, Heikki (2006). Julkishenkilöstön asema: systematiikkaa ja sekamuotoisuutta. Lakimies 7-8/2006, 1158-1176.

L16-14913 (2017) Henkilötodistelu. Päijät-Hämeen käräjäoikeus, oikeuskäsittely jutussa L 16/14913. Nauhoite.

Lehto, Kirsi, \& Viitala, Riitta (2016). ” Enemmän tulosta vähemmällä väellä?": työhyvinvoinnin ja tuloksellisuuden väliset haasteet kuntasektorilla esimiesten, henkilöstöammattilaisten ja henkilöstön kokemana. Hallinnon tutkimus 35 (2016): 2, s. 117-131.

Li, Ji, Moy, Jane, Lam, Kevin \& Chu, W.L. Chris (2008). Institutional pillars and corruption at the societal level. Journal of Business Ethics, 83(2), 327-339. https://doi.org/10.1007/s10551-007-9622-y

Lindström, Anja (2005) Kirkkolain uudistus - tie kirkon toiminnan monipuoliseen kehittämiseen. Ortodoksiviesti 3/2005; 14-15.

Long Play (2020) Arkkipiispa Leo: "Kirkon johtamisjärjestelmä ei kaikilta osin ole riittävän selkeä". Long Play. Sivuäänet 27.5.2020. Haettu sivulta 
https://www.longplay.fi/sivuaanet/arkkipiispa-leo-kirkon-johtamisjarjestelma-ei-kaikilta-osin-ole-riittavan-selkea 18.9.2020

Mattila, Marianne (2020) Long Play: Arkkipiispa Leon perustama Karjalan kielen seura on saanut rahoitusta alun perin Itä-Suomen yliopistolle myönnetystä valtion rahoituksesta.

Yle Uutiset, 24.5.2020. Haettu sivulta https://yle.fi/uutiset/3-11366085 18.9.2020

Mäkinen, Eija (2009). Yliopistojen virkasuhteet työsuhteiksi: miksi?. Hallinnon tutkimus 28 (2009): 71-73.

Mäkinen, Rami (2018) Seurakunta tuomittiin maksamaan Mitro Revolle 30000 euroa. IltaSanomat, 29.3.2018. Haettu sivulta https://www.is.fi/kotimaa/art-2000005622420. html 18.9.2020

Mölsä, Ari (2009) Mitro Revon kantelu pappiskiellosta hylättiin. Yle Uutiset, 14.12.2009, päivitetty 28.5.2012. Haettu sivulta https://yle.fi/uutiset/3-6002752 18.9.2020

Nyström, Arimo (2008) Kirkon tuomioistuimet puuttuvat. Analogi, 5/2008; 18-21.

Ojanperä, Sini (2018) Omin luvin 100000 euroa seurakunnan rahoja ottanut kirkkoherra irtisanottiin - nyt seurakunta joutuu maksamaan hänelle 30000 euron palkat. Yle Uutiset 28.11.2018. Haettu sivulta https://yle.fi/uutiset/3-10530011 18.9.2020

Ortodoksisen kirkon PTS-työryhmä (20008) Etsivä kirkko - Suomen Ortodoksinen kirkko vuonna 2020. Mietintö, 8.10.2008

Paananen, Heli (2008) Jyväskylän ortodoksinen kirkkoherra päihtyneenä pääsiäisaterialla. Keskisuomalainen, 28.3.2008. Haettu sivulta https://www.ksml.fi/paikalliset/2747289 18.9.2020

Paanetoja, Jaana (2015) Euroopan unionin oikeuden työntekijäkäsitteen laajeneva tulkinta. Lakimies, 3-4/2015 s. 367-386.

Palsola, Hannu (2018) Selvitys hiippakuntarajojen jakamisesta ja seurakuntien yhdistämisestä.

Selvitysmiehen selvitys. Ortodoksinen kirkollishallitus. 18.10.2018. Haettu sivulta https://www.ort.fi/sites/default/files/2018-10/ Kirkon\%20hallinnonuudistukseen\%20liittyvä\%20selvitysmiehen\%20selvitys.pdf 18.9.2020

Parrukoski, Timo (toim.) (1989). Ortodoksista kirkkokuntaa koskevia säädöksiä ja määräyksiä. Joensuu: Ortodoksisen kirjallisuuden julkaisuneuvosto.

Paso, Mirjami (2015) Ortodoksisen kirkon hallinnon kehittämistä koskeva hanke ja siihen liittyvät oikeudelliset reunaehdot. Lausunto Suomen ortodoksiselle kirkkohallitukselle. 16.10.2015
Peton, Hélène \& Pezé, Stéphan (2014). The unsuspected dynamics of the regulative pillar: The case of Faute inexcusable in France. M@n@gement, 17(3): 145-179.

https://doi.org/10.3917/mana.173.0001

Powell, Walter W., \& DiMaggio, Paul J. (Eds.). (2012). The new institutionalism in organizational analysis. Chicago: University of Chicago press.

Purmonen, Veikko (2012) Ortodoksipapisto näyttää jääneen kaiken oikeusturvan ulkopuolelle. Helsingin Sanomat, 16.4.2012. Haettu sivulta https://www.hs.fi/mielipide/art2000004868249.html 18.9.2020

Riikonen, Juha, Koponen, Ari \& Metso, Pekka (2020) Ortodoksisen kirkon tulee sitoutua hyvän hallinnon periaatteisiin. Helsingin Sanomat, 29.5.2020. Haettu sivulta https://www.hs.fi/mielipide/art2000006522121.html 18.9.2020

Rytkönen, Jussi (2020) Professori: On ongelma, jos ortodoksipiispat eivät voi yhdessä päättää asioista - Arkkipiispa Leo kiistää kritiikin. Kotimaa24, 17.6.2020. Haettu sivulta https://www.kotimaa24.fi/artikkeli/professori-on-ongelma-jos-ortodoksipiispat-eivat-voi-yhdessa-paattaa-asioista-arkkipiispa-leo-ki/ 18.9.2020

Räikkä, Jyrki (2012) Kirkko kieltää papilta rakkauden. Helsingin Sanomat, 6.4.2012. Haettu sivulta https://www.hs.fi/kotimaa/art-2000004866748. html 18.9.2020

Räinälä, Kari M. (2002) Vastuu kirkkomme tulevaisuudesta. Analogi, 3/2002; 6-7.

Räntilä, Kari M. (2006) Kirkkoneuvos Risto Ikäheimo luotsaa kirkon ensimmäisiä työehtosopimusneuvotteluja. Analogi, 2/2006; 4-5.

Räntilä, Kari M. (2011) Seurakunnat tiukoilla. Analogi 5/2011; 9-11.

Salovaara, Outi (2020) Long Play 89: Monia armorikkaita vuosia. Helsinki: Long Play Oy.

Scott, W. Richard (2008a). Institutions and Organizations: Ideas and Interests. Los Angeles, London, New Delhi, Singapore: Sage Publications.

Scott, W. Richard (2008b). Lords of the dance: Professionals as institutional agents. Organization studies, 29(2), 219-238. https://doi.org/10.1177/0170840607088151

Scott, W. Richard, Ruef, Martin, Mendel, Peter J., \& Caronna, Carol A. (2000). Institutional change and healthcare organizations: From professional dominance to managed care. Chicago: University of Chicago Press.

Siekkinen, Taru (2019). The changing relationship between the academic profession and universi- 
ties in Finnish higher education. Tutkimuksia/ Koulutuksen tutkimuslaitos, (35). Jyväskylä: Jyväskylän yliopisto.

Siltala, Juha (2013). New public management: the evidence-based worst practice?. Administration \& Society, 45(4), 468-493.

doi: https://doi.org/10.1177/0095399713483385

Suddaby, Roy \& Greenwood, Royston (2008) Methodological issues in researching institutional change. Teoksessa: Buchanan, D. \& Bryman, A. (Eds.) The Sage handbook of organizational research methods. London:Sage, s. 176-195.

Suomen ortodoksinen kirkko (2010) Ortodoksinen kirkko Suomessa. Haettu sivulta https://ort.fi/tutustu-ortodoksiseen-kirkkoon/ ortodoksinen-kirkko-suomessa 18.9.2020

Suomen ortodoksinen kirkko (2015) Kirkon tavoite- ja toimintasuunnitelma vuosille 20162020: "Rukoileva ja läsnäoleva kasvun kirkko". Kirkolliskokouksen 26.11.2015 hyväksymä tavoite- ja toimintasuunnitelma vuosille 20162020. Haettu sivulta

https://ort.fi/suomen-ortodoksisen-kirkon-toimintaa-ohjaavat-asiakirjat/tavoite-ja-toimintasuunnitelma-vuosille

Suomen ortodoksinen kirkko (2017) Kirkollishallituksen päätöksiä 10.10.2017. Suomen ortodoksinen kirkko. 10.10.2017. Haettu sivulta https://www.ort.fi/uutishuone/2017-10-10/ kirkollishallituksen-paatoksia-10102017 18.9.2020

Suomen ortodoksinen kirkko (2019) Suomen ortodoksisen kirkon ja sen seurakuntien toimissa noudatettavat rekrytointiperiaatteet. Ortodoksisen kirkkohallituksen kokouksen 14.6.2019 Liite 44 .

Suomen ortodoksinen kirkkohallitus (2006) Eduskunnan hallintovaliokunnan lausuntopyyntö: HE 59/2006 (Lausunto).

T09-26-13_S 18_1122 (2019) Henkilötodistelu. Helsingin hovioikeus, oikeuskäsittely jutussa S 18/1122. Nauhoite, 7.5.2019

T17-04-55_S 18_1122 (2019) Henkilötodistelu. Helsingin hovioikeus, oikeuskäsittely jutussa S 18/1122. Nauhoite, 7.5.2019.

Tarukannel, Veijo (2020) Suomen ortodoksisen kirkollishallituksen 19.2.2020 tekemän päätöksen edellyttämä asiantuntijaselvitys kanonisen oikeuden piirissä työskentelevien toimihenkilöiden työoikeudellisesta asemasta. 22.5.2020. Haettu sivulta https:/ort.fi/sites/default/files/2020-06/
Asiantuntijalausunto\%2C\%20Tarukannel\%20 Veijo.pdf 18.9.2020

Thynell, Tuula (2017) Mitro Repo: "Katson, että tämä on aika törkeä irtisanominen". Yle Uutiset, 5.3.2018. Haettu sivulta https://yle.fi/uutiset/3-10102188 18.9.2020

Toivanen, Meri (2020) Long Play: Kanoniset lait vaikuttavat ortodoksisen kirkon riitojen ja väärinkäytösten taustalla. Kotimaa24. 26.5.2020. Haettu sivulta https://www.kotimaa24.fi/artikkeli/long-play-kanoniset-lait-vaikuttavat-ortodoksisen-kirkon-riitojen-ja-vaarinkaytosten-taustalla/ 18.9.2020

Tolvanen, Matti (2020) Arkkipiispa ei vastaa kaikesta kirkon toiminnassa. Savon Sanomat, 2.6.2020. Haettu sivulta

https://www.savonsanomat.fi/mielipide/lukijan-sanomat/Arkkipiispa-ei-vastaa-kaikestakirkon-toiminnassa/1562986 18.9.2020

Trevino, Len J., Thomas, Douglas E., \& Cullen, John (2008). The three pillars of institutional theory and FDI in Latin America: An institutionalization process. International business review, 17(1), 118-133. https://doi.org/10.1016/j.ibusrev.2007.10.002

Tuppurainen, Elsa (2008) Kirkollishallitus: Purmonen irtisanottiin laillisesti. Helsingin Sanomat, 20.8.2008. Haettu sivulta https://www.hs.fi/kaupunki/art2000004591859.html 18.9.2020

Työ- ja elinkeinoministeriö (2015) Suomen työlainsäädäntö ja työelämän suhteet. Haettu sivulta https://tem.fi/documents/1410877/2918774/ Suomen+työlainsäädäntö+ja+työelämän+suh teet/66681b2a-b817-4f79-8482-9f26091f7602/ Suomen+ työlainsäädäntö+ja+työelämän+suhteet.pdf 18.9.2020

Vaalisto, Heli (2016) Mitro Repo sai potkut - "Luottamus on mennyt kokonaan". Ilta-Sanomat, 9.8.2016. Haettu sivulta https://www.is.fi/kotimaa/art-2000001236320. html

Van de Ven, A. H., \& Poole, M. S. (2005). Alternative approaches for studying organizational change. Organization studies, 26(9), 1377-1404. https://doi.org/10.1177/0170840605056907

Weber, Max (1947). The Theory of Economic and Social Organization. Käännös Henderson, A. \& Parsons, T., alkusanat Talcott Parsons. New York: Free Press.

Yle Uutiset (2009) Mitro Repo ei saa toimia pappina. Yle Uutiset, 26.5.2009. Haettu sivulta https://yle.fi/uutiset/3-5256748 18.9.2020 